\title{
River, Culture and Tourism in Lok Baintan, South Kalimantan
}

\author{
Ellyn Normelani \\ Faculty of Teaching and Education Science, Lambung Mangkurat University, South Kalimantan, Indonesia
}

\begin{abstract}
River become integral part of the Banjarese live in Lok Baitan, South Kalimantan. The economic value of the river has been reported very high. Rivesr is a habitat for numerous fishes which area important for local people along rivers. Rives also provide corridor for people movement. Rivers also place for economic activity. Floating market is a market located at rivers with traditional trader and seller equipped by traditional boat called Jukung. Along the Barito River, floating market point found in two place, Muara Quin and Lok Baitan. Fruit and vegetables are become the mains items in traditional floating market in Lok Baitan. Floating market has its special value for tourism attractions. Continued decrease of youngest generation to the river-based culture economic activity has been the central aspect of the future of floating market. This situation is different for modern market, which is interested among young generation in south Kalimantan. This issue is still present and will remain of great important in the future of floating market.
\end{abstract}

Keywords: culture preservation, floating market, river conservation, South Kalimantan.

\section{INTRODUCTION}

River is an important aquatic ecosystem in the earth. River in the earth is one of the important components of landscape with its wide ecological and social role in the daily life of human being. River is habitat for numerous aquatic fauna, ranging from micro-fauna to macro-fauna which area easily found and observed live in rivers. There are numerous animal, ranging from invertebrates to vertebrates environment. The earth gravity facilitates water movement from headwater in the mountains or high land to the ocean. The process, however, depend on the vegetation quality on earth surface. The conservation of forest therefore contributes significantly in water and rivers ecosystem existence $n$ the earth [1].

In the perspective of anthropocentrism, rivers are important resources to support numerous human activities, ranging from pool of resources which area able to consume to aquatic ways to facilitate human movements. River provides special space for local economic activity. The uses of rivers, however, have been reported unsustainable and lead to the rivers ecosystem disturbance. Scholar point out that many rivers in the world has been widely polluted by numerous toxic substrate, solid waste and liquid waste. In the perspectives of river biology, these disturbances lead to the river species population changes in structure and composition, local spe-

\footnotetext{
* Correspondence address:

Ellyn Normelani

Email : ellyne_melani@yahoo.co.id

Address : Jl. Brigjen Haji Hasan Basri, Banjarmasin.
}

cies extinction and invasion of exotic species. The pollution of numerous toxic substrate lead to the decrease of ability of river to provides fresh water for human and wildlife. Vegetation disturbance has been reported contributes to the decrease of water spring and therefore decrease ability of river to provide water [2,3].

The important of rivers in human life have been reported by numerous authors. Rivers become part of basic aspect to construct community culture. River based culture can be found in every where in the worlds. For instance, in Indian culture, three rivers namely Gangga, Yamuna and Saraswati were views as a representative of the divinities trinity. Saraswati represent the existence of Brahma, Yamuna represents the existence of Vishnu, and Gangga represent the existence of Shiva [4]. In numerous traditional communities in developing countries, some part of the rivers believed as home of the unseen creature. In Java, river has special value and believed as home of unseen creature. Therefore, people should be respect to some place in the rivers ecosystem [5].

In this modern era, river still plays an important role for water-based transportation. Both in modern and developing countries, the role of river to facilitate people moving still dominant. In remotes area, river replaces the role of terrestrial road which are costly to establish. Many city and human settlements located along the river flow represent the important value of rivers in human life. The benefit of the place location near the river is the availability of people moving from one site to other sites. 
River as a natural resource for tourism has been widely reported. Rivers is an important ecosystem to support tourism destination sustainability. Health river provides health water for tourism. Availability of water is crucial in tourism. In the urban area, river is one of the crucial components of urban landscape which area provides special place for urban recreation.

Lok Baitan floating market located at Lok Baitan Village in Sungai Tabuk Sub-district in Banjarese Regency, South Kalimantan. The market has been knows as one of the Banjerese culture in human-economic activity. The aim of the paper is describes the floating market of Lok Baitan, South Kaliman and its potential as tourism attractions. Focus of discussion was to describe the natural and cultural aspect of floating market at Lok Baitan.

\section{Rivers in South Kalimantan}

River is one of the important ecosystem in Kalimantan Island. The ecological function of river has been describes by numerous authors. The roles of river can be classified into three basic categories namely rivers as natural resources as habitat for biota, a media for connectivity, energy, materials, and organisms exchange, and an geomorphical agent for change and disturbance [6]. Rivers ecosystem contributes significantly in the high level of biodiversity in Kalimantan Island, especially aquatic biodiversity. Rivers also maintain wet environment of Kalimantan's land which area crucial for numerous plant species.

About 20 rivers were found in Province of West Kalimantan, 26 river in South Kalimantan, 8 river in Central Kalimantan and 11 rivers in East Kalimantan (Table 1). These rivers has been identified contributes to the daily life of local people and community in Kalimantan Island. The famous and well known rivers are encompasses Barito, Berau, Kapuas River, Kahayan, Lamandau, Mahakam, Martapura, Melawai, Sampit and Sekonyer. Among the ten list of longest river in Indonesia, four rivers were found in Kalimantan Island. It is encompasses Kapuas River (1,143 km), Mahakam River (920 km), Barito River (909 km) and Seruyan River (350 km) [7].

The biodiversity of Kalimantan's rivers was high. Survey by experts in Negara River found about 150 birds species. Mahakam River has received special attention among scholar as a crucial habitat of Pesut Mahakam (Orcaella brevirostris), an endemic animals in world. A conducted survey found that Sekonyer Rivers is home of numerous fish species, including Cyprinidae with ten species, Belontiidae with seven species, Channidae with six, Hemiramphidae with four species and Siluridae with four species [9].

The river in South kalimanan has important value for biodiversity conservation. The rivers in South Kalimantan is home of endemic primate called Nasalis larvatus. This species has been known endemic to South Kalimantan. In some area, peat swamp forest which are related to the rivers ecosystem in South Kalimantan is home of numerous species such as Xylopia sp., Tarantang (Comnaperma sp.) and Nipah (Nipah fruticans). The river in Kalimantan is also important habitat for crocodile, an important predator in Kalimantan rivers and estuary ecosystem. These data shows that rivers in Kalimantan was important habitat that support biodiversity.

\section{River and Human in Kalimantan}

River is an integral part of human life in Kalimantan Island. The original local people in Kalimantan consist of five different groups of community based o the culture, namely Dayak, Banjar, Kutai and Paser [10]. The local people of Kalimantan, called Dayak, absolutely depend on rivers. There are six cluster of Dayaks, namely Ot Danum-Ngaju, Apokayan (Kenyah-Kayan-Bahau), Iban, Murut Klemnatan and Punan. Dayaks often found in the Central of Kalimantan Island. Banjarese occupied Southern area of Kalimantan regions and some coastal area of the island.

Traditionally, Dayaks is the semi nomadic indigenous group in Kalimantan forest. Agriculture become a central part of the Dayaks livelihoods systems. More recently numerous people from Java, Sumatra, Sulawesi and other region in Indonesia come to Kalimantan. Javanese migrates came in such substantial number that they now dominant population in some urban area, such as Balikpapan and Samarinda in East Kalimantan. They uses resources in varying degree, depend on the knowledge and skill levels. Local people in Kalimantan often uses traditional knowledge and local wisdom to use natural resources [11].

An interesting aspect of the local people in Kalimantan is its relationship with river. Rivers is one of the important corridors for Kalimantan local people in movement. Rivers connect numerous communities in Kalimantan Island and therefore contribute significantly in community relationships. 
Table 1. The Rivers of Kalimantan Island

\begin{tabular}{|c|c|c|c|}
\hline $\begin{array}{c}\text { West } \\
\text { Kalimantan }\end{array}$ & $\begin{array}{c}\text { South } \\
\text { Kalimantan }\end{array}$ & $\begin{array}{c}\text { Central } \\
\text { Kalimantan }\end{array}$ & $\begin{array}{c}\text { East } \\
\text { Kalimantan }\end{array}$ \\
\hline Air Hitam & Aingbantai & Kahayan & Angisa \\
\hline Beliang & Alalak & Kalanaman & Bahau \\
\hline Embuan & Amandit & Katingan & Bani \\
\hline Ensabal & Asam-asam & Lamandau & Berau \\
\hline Jelai & Ayu & Mendawai & Kayan \\
\hline Kapuas & Baharangan & Pembuang & Mahakam \\
\hline Landak & Balangan & Sampit & Senyiur \\
\hline Melawi & Barabai & Seruyan & Sesayap \\
\hline Meliau & Barito & & Telen \\
\hline Mengkiang & Batulicin & & Wahan \\
\hline Mempawah & Cegal & & Sembakung \\
\hline Muna & Lilin & & \\
\hline Kedukul & Gelombang & & \\
\hline Paloh & Haruan & & \\
\hline Pawan & Jaing Jangkung & & \\
\hline Sambas & Kurambu Kusan & & \\
\hline Saju & Martapura & & \\
\hline Sekajam & Negara & & \\
\hline \multirow{6}{*}{ Sengarit } & Pitap & & \\
\hline & Riam & & \\
\hline & Satui & & \\
\hline & Tabalong & & \\
\hline & Tabuan & & \\
\hline & Tapin & & \\
\hline
\end{tabular}

The remotes rural dwelling population along rivers live at great distance from city. Therefore has limitation in health, education, economic, and official infrastructure and facility [12].

The economic value of the river has been reported very high. Collecting fish is an important economic and subsistence activity among local dweller along rivers. The fishing methods practiced by local people were very traditional, without modern equipment. Among Dayaks community, man often spend a lot of time to collect fish in the river. Dayaks women involved in agriculture production, and sometimes collect fish in the river. Some of the collected fish from river are consumed by household, and the rest are sold locally in the near market. Some fishes were collected for subsistence. Some fish has the greatest market values, such as Patin (Pangasius mahakamensis), Saluan (Rasbora sp.), Sepat (Trichogaster sp.). Local people recognize the various fish species which have market value. Few studied has been conducted to document the fish collection by local people in Kalimantan's rivers.

River provides numerous resources to meet proteins. Compared to the mammals hunting, however, fishing provides less protein. In Kalimantan, however, fishing still become the important adaptation of human to get proteins. Some fish such as Pepuyu, Haruan, Lais (Ompok hypophthalmus), Patin (Pangasius mahakamen- sis), Saluan (Rasbora sp.), Sepat (Trichogaster sp.), Belida (Chitala chitala), Jelawat (Leptobarbus hoevenii), Kendia (Thynnichthys polylepis), Pari (Himantura polylepis), Baoun (Mytus nemurus) and Galah Mahakam shrimp (Macrobrachium rosenbergii) are the preferred aquatic biota in rivers ecosystem. Fishing is mostly done by men. The local people who live along river followed the same fish collection strategies. It is characterized by the use of traditional equipment.

River has been viewed as home of the ancestors, unseen creators or supra-natural being. It is common among community in developing countries, including people in Kalimantan Island. Local people respect to the rivers represent the harmonious relationship between river and human. Some activity in rivers was taboo and will cause sickness. Some place in the river area guided by ancestor or supranatural being. The proclamation of taboo area by elder or community leader was followed by community. It is significant to protect biodiversity of river. Permission to access taboo area may be granted to particular community member for special purposes. Flooding, disease and some problems related to the live in river ecosystems was perceived to be caused by the failure of community to keep harmonious live of the rivers. Recent modernization however, changes human and rivers relationship. The changes has 
numerous impact, including less appreciation to the rivers. Recent indigenous people in Kalimantan shifting rapidly from traditional to modern life. The important of indigenous knowledge has been decreased significantly. Among young generation, this usually involve changing a spirit to nature and culture.

Many rivers in Kalimantan recently threatened mainly by sedimentation, pollution, and degradations. This is occurs in many big and important rivers which area interact with human life, such as Barito, Mahakam, Asam-asam and Sampit. Scholars point out that the recent industrialization contributes significantly to the water quality of river. This is especially occurs in along the urbanized area. Land uses changes dues to the rapid and massif mining also contributes to the rivers degradations. Most of the recent degraded forest area are located along rivers. The consequences of the logging in the central part of the island has been severe, especially to river quality $[12,13]$

\section{Floating market: the cultural aspect}

Banjarese is one of the dominant local community in South Kalimantan. Trading is an important activity for the Banjarese in Lok Baitan and its surrounding area. Many local people who live along river in South Kalimantan depend on trading and farming to supply numerous resources. The Banjarese along rivers, especially Barito River and Martapura River, has been involve in floating market system since fifteenth century.

Trade is an integral part of the local economic system, and trading activity on rivers is common in South Kalimantan. Several factors contribute to the development of floating market activity among Banjarese in South Kalimantan. There are the interrelationship among available space, transportation and movement media, economic and culture. The limited accesses to the land as market lead to the intensive use of rivers as market place. The floating market is the adaptation of Banjarese live in the limited market infrastructures in the past.

The Banjarese, who are reside along the Barito River in South Kalimantan are among the residential group involve in floating market activity. Selling point are located at some places, such as Muara Quin and Lok Baitan. Women play an important role in floating market. Women is dominant participant in floating market, both as trader or consumer. Women used traditional boat called Jukung to sell numerous commodity which were produced from home garden. Some fruit commodity has highly depend on the season. Barters among trader are still common.

Fruit and vegetables are become the mains items in traditional floating market in Lok Baitan. Depending on the season, fruits are vary in species and number. Fruit and vegetables are by far is the most significant commodity. Trader sold self-produced fruit and vegetables from homegardens. Depending on the amount of commodity, women spend between four to seven hour to sold their commodity in floating market.

\section{Rivers as Tourism Attraction}

Tourism widely recognized as an important factor to trigger local economic development. In the recent decades tourism grows significantly and it is become opportunities for countries with natural and cultural resources to involve in tourism industry. Numerous natural capital has been involved in tourism industry such as lake, mountain, waterfall, water spring, beach and ocean. Place with beauty landscape is the potential site for nature based tourism destination.

The use of rivers ecosystem in tourism industry widely reported. Rivers is an important natural resources for tourism. Some rivers have been used as part of the attraction of tourism destination. In Thailand, there are about 25 rivers with floating market attraction which are a able to generate economic income from tourism sectors. Thailand is very active to increase the environmental services for tourism development [14].

The development of rivers as tourism attraction should be following ecological and social principles. It is because river is a fragile ecosystem and habitat for people which area depend on rivers. The sustainable uses of rivers as tourism attraction are following three principles of development, namely considering social, economical and environmental aspects in the river development.

\section{River, Culture and Tourism in Lok Baitan Floating Market}

Understanding the relationship of river, culture and tourism is a key for sustainable tourism destination, especially in rivers ecosystem. An underlying assumption is that in tourism industry, rivers as part of the natural resources and culture provides unique attraction for destination. Destination without natural and cultural resources are likely to lack power in the recent 
tourism destination competitiveness. More recently, a positive and mutual correlation between culture and tourism has been described [15]. An example of the integration of river, culture and tourism was found and observed in India.

Several aspect may alter river based culture via the decrease of local appreciation to the river and its human culture. The rapid modernization has created river based culture in the recent era, and therefore it is negative to the future tourism development. Several issues should be implemented are encompasses:

- Cooperation among stakeholder in planning the use and conservation of river

- Commitment among local people, government and stakeholder to share the cost and benefits of the effort to conserve rivers

- Increase local participation in rivers conservation

- Creation of more innovative economic activity

- Willingness among stakeholder to support local conservation

Community participation in community based tourism is very low. Provincial government institution generally fails to take any initiative and programs to ensure community participation in tourism development. Similar lack of attention for community based tourism concern also exist at the level of local government and tourism stakeholder. In developing countries, the most successful community based tourism implementation seem to have supported by both international and national NGOs.

A remarkable recent aspect of trade is its relationship with regeneration. Continued decrease of youngest generation to the river-based culture economic activity has been the central aspect of the future of floating market. Young women participation and involvement is very low. This situation is different for modern market, which is interesting among young generation in south Kalimantan. This issue is still present and will remain a great important issue in the future of floating market. There is lack of attention for river based culture education. Numerous NGOs that have worked in Kalimantan Island were primarily worked in nature conservation, especially forest protection. In the future, therefore, it is important for NGOs to preserve floating market in South Kalimantan.

\section{CONCLUSION}

Rivers plays an important role in Banjarese community in North Kalimantan. The economic value of the river has been reported very high. River is a habitat for numerous fishes which area important for local people along rivers. River also provide corridor for people movement. Rivers also place for economic activity. Floating market is a market located at rivers with traditional trader and seller equipped by traditional boat called Jukung. Along the Barito Rivers, floating market point found in two place, Muara Quin and Lok Baitan. Fruit and vegetables are become the mains items in traditional floating market in Lok Baitan. Floating market has its special value for tourism attractions. Continued decrease of youngest generation to the river-based culture economic activity has been the central aspect of the future of floating market. This situation is different for modern market, which is interesting among young generation in south Kalimantan. This issue is still present and will remain of great important issue in the future of floating market.

\section{REFERENCES}

[1] Wetzel, R. G. 2001. Limnology: lake and river ecosystems. Gulf Professional Publishing.

[2] Galay, V. J. 1983. Causes of river bed degradation. Water Resources Research 19(5), 1057-1090.

[3] Karr, J. R. 1999. Defining and measuring river health. Freshwater Biology 41(2), 221234.

[4] Ramakrishnan, P. S. 2003. The sacred Ganga river-based cultural landscape. Museum International 55(2), 7-17.

[5] Whitten, A. J. R. E. Soeriaatmadja and S. Afiff. 1996. The ecology of Java and Bali. Periplus. Singapore.

[6] Sponseller, R. A., J. B. Heffernan and S. G. Fisher. 2013. On the multiple ecological roles of water in river networks. Ecosphere 4(2), 17.

[7] Central Statistc Office. 2014. River in South Kalimantan. Central Statistic of South Kalimantan.

[8] van Balen, B. and C. Prentice. 2011. Birds of the Negara River Basin, South Kalimantan, Indonesia. Kukila 9, 81-107.

[9] Nurudin, F. A. 2013. Keanekaragaman jenis ikan di Sungai Sekonyer Taman Nasional Tanjung Putting Kalimantan Tengah. State University of Semarang. Semarang. 
[10] Syamsuddin, H. 2004. Desentralisasi dan otonomi daerah: naskah akademik dan RUU usulan LIPI. Yayasan Obor Indonesia. Jakarta, 188.

[11] MacKinnon, K. 1996. The ecology of Kalimantan, Vol. 3. Oxford University Press.

[12] Gastaldo, R. A. and A. Y. Huc. 1992. Sediment facies, depositional environments, and distribution of phytoclasts in the Recent Mahakam River delta, Kalimantan, Indonesia. Palaios, 574-590.

[13] Douglas, I., T. Greer, K. Bidin and M. Spilsbury. 1993. Impacts of rainforest logging on river systems and communities in Malaysia and Kalimantan. Global Ecology and Biogeography Letters, 245-252.

[14] Boonratana, R. 2010. Community-based tourism in Thailand: The need and justification for an operational definition. Kasetsart Journal: Social Sciences 31(2), 280-289.

[15] Butler, R. and T. Hinch. 2007. Tourism and indigenous peoples: Issues and implications. Routledge. 